\title{
15. European justice in times of the Corona crisis: some preliminary reflections
}

\author{
Trudie Knijn and Dorota Lepianka
}

\subsection{REPRESENTATION, REDISTRIBUTION AND RECOGNITION: REVISED OR ACCENTUATED?}

At the time we conducted our research, wrote our chapters and composed this book, the Corona virus and the pandemic it caused was far behind the horizon. Today - April 2020, when we are writing the afterword, 'old normality' has disappeared, which allows and even urges us to reflect - preliminarily - on the meaning of justice in Europe in an era where political, economic, social and cultural relations are undergoing a radical shake-up. What does this immense drama of almost 150,000 deaths in Europe only tell us about justice on the continent? Do the principles of justice that we unravelled in our ETHOS study help us understand how Europe reacts to the needs of nation states and its populations, or are new principles applied? Are the already vulnerable populations sufficiently protected or have they become even more vulnerable? Have new categories of vulnerable populations come to the fore? And are old boundary lines that define the 'ins' and 'outs' of justice sustained, or resolved? Are new lines being drawn?

As said, these are only preliminary reflections as the Corona virus continues to proliferate and its ultimate effects are not yet to be foreseen. While competing schemes of justice are continuously fought over and reformulated, the scale and the depth of the Corona crisis appears to induce European and national politicians to search for unity at a unique speed and scale. This 'closing of ranks', however relative, can be cautiously viewed as an indication that European leaders have learned from the failed, disastrous reactions to the previous crises - economic and financial. It shows as well that, at least under such extraordinary circumstances, political thinking in terms of values is not entirely dead, and that attempts to combine moral and economic reasoning, 
and stepping beyond national egoism in the name of common good and future perspectives is still (or again) possible.

Of the three battlefields of justice that form the core of the concept of 'participatory parity' explored in this book and in the ETHOS research project - redistribution, recognition and representation - it is representative justice that these days appears crucial. Having a say in political decision making on the distribution of funds that are needed to rescue national economies, and inherently the economy of Europe at large, constitutes one of the main issues in question. Who is to make the decisions if not the European Central Bank that is, in principle, devoid of any political decision-making power? Is it the European Council, consisting of the heads of Member States? The European Commission? Or the European Parliament - the only European institution chosen in democratic elections? How does the unique European Union (EU) multi-level governance operate? On what grounds are decisions being made?

After a lot of deliberation and mutual insults, frequently wrapped in nationalistic framing, a political compromise has been reached on the support for Southern European countries that have been particularly strongly hit by the Corona crisis. Nonetheless, important justice-related questions remain. One could wonder, for example, if 'customary' procedures of representation should have been applied here, in the sense that national parliaments should have been consulted and/or asked for approval for the decisions made, or whether the fact that national parliaments had been only marginally involved has been a blessing for the EU as an integration project, faithful to the values of justice and solidarity. After all, one may say that compromises on representative justice have had to be made in order to protect European countries against the operations of speculative financial markets. The risk of rating agencies downgrading national economies and, by implication, increasing interest rates for state loans had to be avoided. At the same time, the clash between some countries (in this case the Netherlands and Italy) on reducing national debts in times of an all-compassing external disaster shows the risk of viewing justice principally through the lens of 'national interest' and/or what is conceived as national interest by politicians focused principally on their domestic electorate.

Representative justice in Europe - and beyond - is also at stake where autocratic leaders misuse the pandemic to strengthen their authoritarian power and to further supress the already restricted, often critical, voice of citizens, media and advocacy organizations. In two of the countries involved in our ETHOS project - Hungary, a Member State of the EU - and Turkey, a member of the Council of Europe - political leaders in power abuse the pandemic to brutally muzzle all oppositional voices. Moreover, in Turkey ten thousands of imprisoned political opponents' lives are in danger while they are still not proven guilty and are waiting for their trial. 
But there is more to say on representative justice in the context of the crisis. As pointed out in some of the chapters of this volume (Chapters 8 to 11), vulnerable groups are easily forgotten; especially those in a particularly precarious situation (older citizens, care workers, minority members) hardly have a say. In the magnitude of the pandemic and efforts to combat its effects, it is the experts and politicians who determine the hierarchies of deservingness (see also Chapter 8). In the division of scarce resources (protection materials, medicines, Corona tests), the interests of the cure sector prevail above those of the care sector, often at the cost of death for many older citizens and serious health risk for care workers (Chapter 10). Similarly, voices representing refugees and/or minority members (Chapter 8), who are at a greater risk of infection and less likely to receive necessary care, are lost in the national (media) debates. Also mobile workers and people on flexible contracts, most of whom are young, find it much more difficult to have their interests represented, and to get their fair share of protection measures, than workers with permanent contracts and more labour market security (compare Chapter 11).

Regarding redistributive justice, the Corona pandemic clearly illustrates the enormous costs of the neo-liberal efforts to develop a competitive European market. It shows the disastrous effects of austerity responses to financial and economic crises, in which taxes have been used to save the 'sinners' responsible for the crises - financial actors and institutions, such as banks and their shareholders, at the cost of public services, healthcare, education, the cultural sector, and people working in these domains. Suddenly, in the face of the pandemic, it becomes clear how vital public sectors and their employees are and how neglected and undervalued they have been in an ideological attempt to economize public interest and subjugate it to the logic of the market.

Redistributive justice is also at stake in the fragmented and liberalized labour market, where social protection of workers has been systematically undermined by celebrating the 'liberation' from permanent jobs as a form of 'freedom'. The discourse and practice of flexibility (without security) now boomerangs back to hit millions of Europeans who, under the conditions of lockdown and 'social distancing' introduced to slow the rapidity of epidemic growth, lose their jobs, income, healthcare insurance, and who might have trouble paying rent in the coming months. A positive reaction of the EU on the looming economic recession is the installation of a European unemployment fund, in line with the proposal of Vandenbroucke (2020). Indeed, a deep crisis was needed to seriously consider and readily implement the idea that

the EU should become a European Social Union, that is a union that supports the member states' welfare states in some of their key functions, on the basis of common social standards and in pursuit of upward convergence. Such a union 
would be a (selective) Support, Guide and Guarantor, both in the realm of insurance and redistribution. (Vandenbroucke 2020, p. 37)

In addition, nation states implement all kinds of compensations for companies, employees and self-employed workers, through subsidies, loans and welfare benefits, which not long ago, and under the dominant logic of neo-liberalism, was unimaginable.

Nevertheless, all those measures, however laudable, should be viewed as a reaction to the crisis caused by the Corona pandemic. Their implementation here and now does not guarantee that the maldistribution, reflected in soaring poverty, increased social insecurity and inequality within and between Member States, which for years has undermined the European Social Model, will continue to diminish after this crisis. Indeed, the state is back in, but it remains to be seen whether this could be explained as a matter of 'economizing justice' (Castro Caldas 2018; see also Chapters 4 and 11) or as a lasting reorientation on the previously common standards of distribution.

The first signs are not yet comforting; in efforts to save companies from bankruptcy, generic financial support does not - in principle - discriminate between big market players, who in the past few years have transferred millions to their already rich shareholders, evaded paying taxes and have not refrained from firing their flex-workers at the outset of the current crisis (hence, current protests against subsidizing Booking.com, KLM/Air France or Virgin Group), and small entrepreneurs, who struggle to survive and save the jobs and income of their relatively few employees. Questions arise as well about who will cover the costs of public services during and beyond the pandemic. Will banks and other financial institutions, as well as their shareholders, reconsider their greediness and, by paying their share of taxes, finally contribute to keeping the public sphere alive and healthy? Will we witness a rise of a new generation of politicians who will stand up for social services and defend their right to flourish as a vital part of a democratic social order rather than a mere economic cost? There is a lesson to be learned here. An idea of a specifically and uniquely European approach to redistributive justice and solidarity is still vivid among European citizens but it remains to be seen to what extent this idea is shared by actors who dominate our political and, especially, economic institutions.

Recognitive justice, like other aspects of 'participatory parity', touches upon Europe's normative ambitions. This volume shows that, within the EU, in policy and daily practice 'justice' often appears to be a multi-interpretable, situationally applicable instrument for identity politics and/or recognition of individual and categorical needs and rights, such as those of persons with a disability, older citizens, women, migrants and/or ethnic minorities. The Corona pandemic makes us painfully aware of the situated vulnerability of 
some neglected categories of the population. Older citizens appear to be more vulnerable to the virus and among the casualties there are many people of age. However, it is also crystal clear that the increased death rate among older people is not only 'identitarian', that is, related to the age category they belong to, but also a consequence of inadequate public health policy, which fails to protect the most vulnerable. While many vulnerable elderly and/or disabled people, whether living alone or in nursing homes, depend on care services, home care providers and care institutions became the last in line for necessary protection, both for their clients and the predominantly female employees (see also Chapter 10). Under the current crises, the cross-cutting categories of gender, old age, disability and class (underpaid care workers), often discussed under the banner of 'intersectionality', become real human beings whose lives are neglected and possibly sacrificed. Issues of gender equality and gendered division of labour acquire new relevance. Working in the already undervalued and underpaid care sector, female care workers continue, mostly unprotected, to take care of elderly and/or disabled people. While their often heroic work receives a lot of appreciation and is applauded, both by the public and the politicians, very practical questions arise as to whether that appreciation will bring concrete rewards in terms of salaries, but also job security and better working conditions. Deplorable conditions in understaffed nursing homes are a consequence of public cutbacks, which disproportionally hit mostly female care workers. Public applause, however sincere, is not enough: symbolic recognition of care work as a vital profession that is instrumental to the well-being of some of the most vulnerable social groups must be coupled with redistribution and work-autonomy, which in the current crises, should translate into, for example, care workers having more of a say on the distribution of vital protection measures.

\subsection{VULNERABILITY: COMMON AND CONDITIONAL}

Vulnerability is a core concept in the ETHOS research and in this volume. Above, we hinted at how the crisis has hit most vulnerable groups and sectors within the political communities of the nation states and the EU at large. Equally important, however, is the commonality of vulnerabilities among the European population as well as its double character as an ontological aspect of human life and a conditional phenomenon. This double character of vulnerability, discussed in Chapters 1 and 3, has become most topical in the context of the Corona crisis. The commonality of vulnerability implies that no one can escape from being affected by the disease, whether by getting infected, by coping with the infection and its consequences among loved ones, or by being affected by the consequences of lock-downs. Living under mild or strict 
lock-down conditions, dealing with insecurity about current and future income or working conditions, being estranged from affectionate bodily contact with friends and extended kin hit all. It goes for people with obesity as well as for the 'physically fit'; for the homeless as well as for the 'hard-working men and women' in so-called 'vital sectors' (healthcare, education, construction work, supermarkets, distribution centres, taxi- and bus-services, truck drivers); for flex-workers, artists and even for top managers of sectors that until very recently cherished the thought of being untouchable (such as Uber, Airbnb or temporary job agencies). The commonality of vulnerability shows its ontological character - people are inherently fragile. Greater awareness of human interdependency might be then yet another lesson to be taken from the Corona crisis. Such an awareness may help to develop a model of co-existence that would form an alternative, however humble and modest in the beginning, to the neo-liberal self-centrism.

This, however, does not take away the relevance of conditionality. As discussed above (and in Chapters 1 and 3), circumstances determine to a great extent the (individual) capability to cope with vulnerabilities of whatever kind. In Chapter 3, we have quoted Mackenzie $(2014$, p. 7$)$ saying that vulnerability 'may be caused or exacerbated by the personal, social, political, economic, or environmental situations of individuals or social groups'. Strikingly illustrative for that statement, in the current Corona crisis, is the ambivalent attention for (European) populations who lack citizenship of the country where they live or work. The ambivalent consequences of sedentarian as well as territorial boundary drawing (discussed in Chapters 8 and 14) become particularly apparent in the case of two groups: foreign workers and refugees, and in two respects: pragmatic and moral. First, closing European borders (for mobile workers and seasonal labourers from within and outside of Europe) hit both the (unprotected) mobile workers, who lost their income, and their employers all over Europe, who become painfully aware of the economic and social indispensability of agricultural day labourers and/or informally contracted home care workers from abroad. The crisis painfully manifests the disastrous consequence of the non-acknowledgement (and non-recognition) of foreign mobile workers as contributors to Europe's well-being and prosperity and of keeping a blind eye to the exploitive labour relations under which they worked and lived. Second, the continued negligence of refugees hits back severely on European values and human rights ideals. To leave refugees locked up, forgotten or abandoned in camps at the European borders is an absolute denial of what Europe claims to stand for. Although small steps have been taken by moving a few thousand refugees from some shabby camps on the Greek islands to some better-equipped camps on the Greek mainland, and by some EU Member States adopting parentless refugee children (with one of our ETHOS countries of investigation, the Netherlands, refusing to show this 
humanitarian approach), this misery questions the centrality of justice in the moral core of Europe.

\subsection{DIVERSITY AND PRAGMATISM AS CORE ISSUES OF AN EMPIRICALLY BASED THEORY OF JUSTICE IN EUROPE}

What this Corona crisis and the subsequent reactions teach us is that a European theory of justice and fairness cannot reach beyond a pragmatic approach that recommends building 'a piecemeal theory of justice for particular constellations' (Van den Brink, Zala and Theuns in Chapter 12). Human and societal diversity create space for a multiplicity of human needs and desires and lead to varying, and sometimes competing, justice claims. Also, in Europe the growing social and cultural, but also ethnic and religious, diversity results in the co-existence, not always peaceful, of conflicting schemes of values and ideas of what is just and what constitutes a just society. The results of our empirical research presented in Chapters 5 to 11 show how differently the seemingly similar justice-related issues might be understood in different countries and/or by different social groups. They also show that European states differ in their approach to and protection of vulnerable groups, for example, by guaranteeing different rights and entitlements and/or putting forward different obligations as conditions for entitlements.

The complexity exposed by our empirical investigations raises serious doubts as to whether one normative framework of justice is likely to successfully account for all the institutional, social and cultural contexts that Europe is so rich in. Indeed, the fundamental message conveyed in this volume is that the development of a commonly shared monolithic European theory of justice and fairness is impossible. An alternative we propose involves developing a theory that is sensitive to particular forms and constellations of injustice that appear in concrete social contexts. This involves combining solid normative reasoning with empirical research and policy analysis in order to comprehend, as much as possible, 'why [a policy area] generates moral difficulties, and then to connect those difficulties or dilemmas with patters of philosophical reasoning and reflection' (Wolff 2011, p. 9). Importantly, such an approach would allow us to account for the role of incremental changes, gradual and sometimes relatively negligible transitions away from manifest injustice (see Chapter 2). Seen from such a perspective, and scrutinized under regular conditions, Fraser's distinction between affirmative remedies to injustice, which seek to rectify inequalities without radically altering the structural and cultural relations from which they are produced, and transformative remedies, which seek to radically reform these structures and cultures, loses its relevance. As noted by van den Brink, Zala and Theuns (Chapter 12), empirical explorations 
undertaken as part of our project, and partly presented in Chapters 5 to 11, show that 'wholesale' transformative remedies to injustice are not always attainable and/or desirable. Indeed, they seem highly unlikely under the conditions of 'old normality'.

Nevertheless, as the Corona crisis shows, radical reforms that challenge structural as well as cultural relations are not only possible, but - at least under the current crises - necessary, although their long-term effects might appear dubious. Moreover, transformative politics is possible within the existing institutional structure: the liberal welfare state and mainstream multiculturalism. What the ETHOS project thus proposes is combining the best possible affirmative strategies, strategies that are open for 'second best' remedies in everyday life, inclusive and likely to impede at least some of the mechanisms that generate injustice (Chapters 13 and 14), with a more thorough analysis of structural injustices that could lead to transformative restructuring of the institutional context. If the pandemic might have a positive effect, it could be this.

\section{REFERENCES}

Castro Caldas, José (2018), 'Report on economizing on justice', ETHOS report D6.1, accessed 27 September 2018 at https://www.ethos-europe.eu/.

Mackenzie, Catriona, Wendy Rogers and Susan Dodds (2014), 'Introduction: what is vulnerability, and why does it matter for moral theory?', in Catriona Mackenzie, Wendy Rogers and Susan Dodds (eds), Vulnerability: New Essays in Ethics and Feminist Philosophy, Oxford: Oxford University Press, pp. 1-29.

Vandenbroucke, Frank (2020), 'Solidarity through redistribution and insurance of incomes: the EU as Support, Guide, Guarantor or Provider?', SSRN Research Paper 2020/01, Amsterdam: The Amsterdam Centre for European Studies, accessed 23 April 2020 at https://ssrn.com/abstract=3530876.

Wolff, Jonathan (2011), Ethics and Public Policy: A Philosophical Inquiry, London: Routledge. 